\title{
HUBUNGAN INTERAKSI EDUKATIF DENGAN MINAT BELAJAR MATEMATIKA SISWA KELAS IV,V,VI DI SD MUHAMMADIYAH POLANHARJO KLATEN TAHUN PELAJARAN 2019/2020
}

\author{
Bekti Ayu Ariastuti \\ IAIN Surakarta \\ E-mail: Bektiiayu7@gmail.com
}

\begin{abstract}
This study aims to determine: 1) high class educational interactions in mathematics learning activities; 2) high class students' interest in learning mathematics; 3) the relationship between educational interactions with the interest in learning mathematics of high class students at SD Muhammadiyah Polanharjo Klaten for the 2019/2020 academic year. The research method used is quantitative with correlational analysis. This research was conducted at SD Muhammadiyah Polanharjo Klaten in the even semester of the 2019/2020 school year. The population in this study were all high-grade students at SD Muhammadiyah Polanharjo with a total of 88 students. A sample of 72 students was calculated using the Slovin formula with an error rate of 5\%. Sampling was done by using Proportionate Stratified Random Sampling technique. Data collection techniques in this study used a questionnaire instrument that had been tested for validity and reliability. Based on the research results, it can be concluded that 1) the level of educational interaction is in the good category, namely 57\%;2) Students' interest in learning mathematics obtained a percentage of $65 \%$ with a good category; 3 ) Based on the results of the correlation test with $r$ count $=0.509, r$ table $=0.227$, then $r$ count $>r$ table. So HO is rejected and $\mathrm{Ha}$ is accepted, so it can be concluded that there is a positive relationship between educational interaction with the interest in learning mathematics of high class students at SD Muhammadiyah Polanharjo Klaten in the 2019/2020 academic year.
\end{abstract}

Keywords: Educational Interaction; Learning Interest; Mathematic

\begin{abstract}
Abstrak Penelitian ini bertujuan untuk mengetahui: 1) interaksi edukatif kelas tinggi dalam kegiatan pembelajaran matematika; 2) minat belajar matematika siswa kelas tinggi; 3) hubungan antara interaksi edukatif dengan minat belajar matematika siswa kelas tinggi di SD Muhammadiyah Polanharjo Klaten Tahun Pelajaran 2019/2020. Metode penelitian yang digunakan adalah kuantitatif dengan analisis korelasional. Penelitian ini dilaksanakan di SD Muhammadiyah Polanharjo Klaten pada Semester Genap Tahun ajaran 2019/2020. Populasi dalam penelitian ini adalah seluruh siswa kelas tinggi di SD Muhammadiyah Polanharjo sejumlah 88 siswa. Sampel sejumlah 72 siswa yang dihitung dengan menggunakan rumus slovin dengan taraf kesalahan 5\%. Pengambilan sampel dengan teknik Proportionate Stratified Random Sampling. Teknik pengumpulan data dalam penelitian ini menggunakan instrument angket yang telah diuji validitas dan reabilitasnya. Berdasarkan hasil penelitian, dapat disimpulkan bahwa 1) Tingkat interaksi edukatif termasuk kedalam kategori baik yaitu sebesar 57\%; 2) Minat belajar matematika siswa diperoleh persentase $65 \%$ dengan kategori baik; 3) Berdasarkan hasil uji korelasi dengan $r_{\text {hitung }}=0,509, r_{\text {tabel }}=0,227$, maka diperoleh $r_{\text {hitung }}>r_{\text {tabel. }}$. Maka $\mathrm{H}_{0}$ ditolak dan $\mathrm{H}_{\mathrm{a}}$ diterima, sehingga dapat disimpulkan bahwa terdapat hubungan yang positif antara interaksi edukatif dengan minat belajar matematika siswa kelas tinggi di SD Muhammadiyah Polanharjo Klaten tahun pelajaran 2019/2020.
\end{abstract}

Kata Kunci : Interaksi Edukatif; Matematika; Minat Belajar 


\section{PENDAHULUAN}

Matematika merupakan suatu ilmu yang berada di setiap aspek kehidupan manusia. Dalam kehidupan sehari-hari matematika banyak digunakan untuk menyelesaikan permasalahan-permasalahan dan juga digunakan sebagai sumber berbagai ilmu pengetahuan. Oleh sebab itu, matematika sangatlah penting untuk diajarkan sejak dini. Matematika dipelajari hampir di setiap jenjang pendidikan, mulai dari taman kanak-kanak sampai dengan perguruan tinggi, bahkan dalam dunia kerjapun matematika masih digunakan (Turmudi, 2012: 7). Sayangnya, kebanyakan siswa menganggap bahwa matematika merupakan pelajaran yang sulit. Menurut penelitian Sugilar (2013) bagi siswa yang menganggap matematika menyenangkan maka minat belajarnya tinggi, sedangkan bagi siswa yang memiliki minat belajar yang rendah terhadap matematika, akan menganggap matematika sebagai pelajaran yang sulit.

Menurut Kompri (2017: 143) faktor-faktor yang mempengaruhi minat belajar ada 2 yaitu faktor internal dan eksternal. Faktor internal meliputi faktor jasmani, faktor psikologis dan faktor kelelahan. Sedangkan faktor-faktor eksternal yang mempengaruhi minat belajar meliputi: tujuan pengajaran, guru yang mengajar, bahan pelajaran, metode pengajaran, media pengajaran dan lingkungan. Faktor eksternal yang sangat erat kaitannya dengan minat belajar siswa salah satunya adalah guru yang mengajar. Dalam proses pembelajaran guru harus mampu menjalin hubungan yang baik dengan siswa. Di dalam relasi guru dengan siswa yang baik, siswa akan menyukai gurunya, juga akan menyukai mata pelajaran yang diajarkan sehingga siswa berusaha mempelajari sebaik-baiknya. Guru yang kurang berinteraksi dengan siswa secara akrab, menyebabkan proses belajar mengajar kurang lancar (Slameto, 2010: 66).

Berdasarkan wawancara dan observasi ditemukan masalah pada kegiatan proses pembelajaran di SD Muhammadiyah Polanharjo tahun pelajaran 2019/2020. Berdasarkan hasil wawancara dengan guru-guru kelas tinggi bahwa pada saat guru memberikan PR (pekerjaan rumah) matematika kepada siswa, pasti ada beberapa siswa yang belum mengerjakan PR tersebut. Ada siswa yang tidak membawa buku pelajaran matematika. Alasannya adalah lupa tidak membawa buku. Berdasarkan hasil observasi terlihat guru masih kurang dalam menciptakan interaksi pembelajaran yang menarik seperti kurangnya variasi metode, penggunaan media atau alat bantu dalam menyampaikan materi pelajaran. Hal ini menjadikan siswa lebih cepat bosan dan jenuh dalam mengikuti pelajaran. Selain itu, guru juga terlihat memilih-milih siswa, terlihat ketika siswa disuruh mengerjakan soal-soal latihan di papan tulis. 
Guru cenderung hanya menunjuk siswa yang pandai saja. Hal ini menunjukkan interaksi edukatif antara guru dan siswa kurang baik.

Interaksi yang terjadi pada saat kegiatan pembelajaran disebut juga dengan interaksi edukatif. Menurut Sardiman (2011: 8) interaksi edukatif merupakan hubungan komunikasi yang terjadi antara guru dan siswa pada saat kegiatan pembelajaran berlangsung. Hubungan ini dilakukan secara sadar dan sudah direncanakan untuk mencapai tujuan pembelajaran. Kegiatan interaksi yang efektif antara guru dan siswa akan mempermudah siswa untuk menerima dan mempelajari materi pelajaran dengan baik. Berdasarkan permasalahan yang terjadi, permasalahan tersebut menarik untuk dikaji dengan judul Hubungan Interaksi Edukatif dengan Minat Belajar Matematika Siswa Kelas Tinggi di SD Muhammadiyah Polanharjo Klaten Tahun Pelajaran 2019/2020.

\section{METODE PENELITIAN}

Penelitian ini menggunakan metode kuantitatif dengan analisis korelasional, bertujuan untuk mengetahui ada tidaknya hubungan interaksi edukatif dengan minat belajar matematika siswa kelas tinggi di SD Muhammadiyah Polanharjo Klaten tahun pelajaran 2019/2020. Populasi yang digunakan adalah siswa kelas tinggi yaitu kelas IV, V dan VI di SD Muhammadiyah Polanharjo Klaten tahun pelajaran 2019/2020 sebanyak 88 siswa. Sampel dalam penelitian adalah 72 yang diperoleh emnggunakan Proportionate Stratified Random Sampling. Teknik pengumpulan data dalam penelitian ini menggunakan angket. Uji normalitas pada penelitian ini menggunakan uji Kolmogorov-Smirnov dan pengujian hipotesis dengan menggunakan korelasi product moment.

\section{HASIL DAN PEMBAHASAN}

Interaksi edukatif memiliki hubungan dengan minat belajar seorang siswa di sekolah (Fahyuni \& Istikomah, 2016). Proses interaksi itu pihak pengajar mampu menarik perhatian siswa agar siswa dapat berminat dalam mengikuti pembelajaran yang sedang berlangsung. Adanya interasi pembelajaran yang baik dapat menjadikan kegiatan pembelajaran berjalan dengan optimal dan dapat mencapai suatu tujuan pembelajaran.

Berdasarkan angket Interaksi edukatif dan minat belajar matematika diperoleh hasil yang berupa skor, diperoleh hasil dari angket interaksi edukatif bahwa skor terendah 68 dan skor tertinggi 100. Kemudian skor interaksi edukatif tersebut dibuat dalam tabel frekuensi dengan 3 kategori yaitu kurang baik, baik dan sangat baik. Sedangkan dari angket minat belajar 
matematika diperoleh hasil skor terendah 80 dan skor tertinggi 126 . Kemudian skor interaksi edukatif tersebut dibuat dalam dengan 3 kategori yaitu rendah, sedang dan tinggi.

Uji normalitas pada penelitian ini menggunakan uji Kolmogorov-Smirnov. Berdasarkan hasil perhitungan uji normalitas One-Sample Kolmogorov Smirnov dan dapat diketahui bahwa data variabel interaksi edukatif diperoleh nilai Asymp Sig. (2-tailed) sebesar 0,200 lebih besar dari 0,05, menunjukkan bahwa distribusi data dalam penelitian adalah normal. Hasil perhitungan uji normalitas One-Sample Kolmogorov Smirnov dapat diketahui bahwa data variabel minat belajar matematika siswa diperoleh nilai Asymp Sig. (2-tailed) sebesar 0,200 lebih besar dari 0,05, menunjukkan bahwa distribusi data dalam penelitian adalah normal. Dengan demikian dapat disimpulkan bahwa data interaksi edukatif dan minat belajar matematika siswa berdistribusi normal.

Pengujian hipotesis dengan menggunakan korelasi product moment untuk mengetahui hubungan keduanya. Berdasarkan hasil uji korelasi di atas diperoleh dari variable interaksi edukatif dengan minat belajar matematika siswa kelas tinggi SD Muhammadiyah Polanharjo Klaten tahun pelajaran 2019/2020 dengan $\mathrm{r}_{\text {hitung }}=0,509, \mathrm{r}_{\text {tabel }}=0,227$, maka diperoleh $\mathrm{r}_{\text {hitung }}(0,509)$ $<\mathrm{r}_{\text {tabel }}(0,227)$. Maka $\mathrm{H}_{0}$ ditolak dan $\mathrm{H}_{\mathrm{a}}$ diterima. Dengan demikian dapat disimpulkan bahwa terdapat hubungan yang positif antara interaksi edukatif dengan minat belajar matematika siswa kelas tinggi di SD Muhammadiyah Polanharjo Klaten tahun pelajaran 2019/2020.

Menurut Lestari (2013) minat belajar secara langsung dapat mengubah perilaku belajar siswa menjadi lebih peduli terhadap belajar sehingga tujuan pembelajaran pun dapat tercapai. Ketika siswa siswa menyukai matematika maka dengan sendirinya siswa akan belajar dnegan sungguh-sungguh sehingga mendapatkan hasil belajar yang baik, hal ini sejalan dengan penelitian Mutakin (2011) bahwa "terdapat pengaruh minat belajar terhadap hasil belajar matematika". Lestari (2013) juga mendukung penelitian tersebut bahwasanya sesorang yang memiliki minat belajar yang tinggi tidak akan memiliki hambatan dalam belajar. Interaksi siswa dengan guru atau interaksi edukatif memiliki hubungan dengan minat belajar siswa. Apabila interaksi edukatif yang didukung dengan minat belajar maka akan mempengaruhi hasil belajar matematika siswa. Semakin besar interaksi edukatif dengan minat besar maka semakin besar pula hasil belajar siswa (Febriyanti \& Serumi, 2014; Widiyawati , 2013; Haryati, 2015; Daniyati, 2015; Astuti, 2015; Siagian, 2015; Sirait, 2016; Purnama, 2016; Handayani, 2016; Heriyati, 2017; Ratnasari, 2017; Putri, 2017; Lase, 2018; Sari dkk, 2019; Fitriyani, 2019; Islamiah, 2019). 
Interaksi edukatif sangat diperlukan dalam pembelajaran terutama pada mata pelajaran matematika untuk menghindari pembelajaran satu arah atau teacher center, sehingga dalam interaksi edukatif ini lebih membebaskan siswa menyumbangkan pikiran dalam menjawab pertanyaan dalam pembelajaran. Hal positif dengan adanya interaksi edukatif ini dapat meningkatkan hasil belajar siswa sejalan dengan penelitian Rahma \& Ardani (2018). Interaksi edukatif dalam penelitian ini menentukan minat belajar yang berpengaruh terhadap hasil belajar siswa. Penelitian ini juga didukung berdasarkan hasil penelitian Susintoi (2019) yang menyatakan interaksi belajar menentukan hasil belajar siswa, sehingga guru perlu untuk membiasakan dalam melakukan interaksi belajar baik di dalam kelas maupun pada saat istirahat ketika di sekolah.

\section{KESIMPULAN}

Berdasarkan hasil penelitian yang telah penulis kemukakan dan pembahasan yang telah diuraikan, maka dapat ditarik kesimpulan bahwa: (1) Tingkat interaksi edukatif pada pembelajaran matematika siswa kelas tinggi di SD Muhammadiyah Polanharjo Klaten tahun pelajaran 2019/2020 termasuk kedalam kategori baik diperoleh siswa sebanyak 41 atau 57\% dari 72 siswa. (2) Minat belajar matematika siswa kelas tinggi di SD Muhammadiyah Polanharjo Klaten berada dalam kategori sedang diperoleh siswa sebanyak 47 atau 65\% dari 72 siswa. (3) Berdasarkan hasil uji korelasi di atas diperoleh dari variabel interaksi edukatif dengan minat belajar matematika siswa kelas tinggi SD Muhammadiyah Polanharjo Klaten tahun 2019/2020 dengan $r_{\text {hitung }}=0,509, r_{\text {tabel }}=0,227$, maka diperoleh $r_{\text {hitung }}(0,509)>r_{\text {tabel }}(0,227)$, maka $H_{0}$ ditolak dan $\mathrm{H}_{\mathrm{a}}$ diterima. Dengan demikian dapat disimpulkan bahwa terdapat hubungan yang positif antara interaksi edukatif dengan minat belajar matematika siswa kelas tinggi di SD Muhammadiyah Polanharjo Klaten tahun pelajaran 2019/2020.

\section{DAFTAR PUSTAKA}

Astuti, S. P. (2015). Pengaruh kemampuan awal dan minat belajar terhadap prestasi belajar fisika. Formatif: Jurnal Ilmiah Pendidikan MIPA, 5(1): 68-75.

Daniyati, N. A., \& Sugiman, S. (2015). Hubungan antara kemampuan verbal, kemampuan interpersonal, dan minat belajar dengan prestasi belajar matematika. PYTHAGORAS: Jurnal Pendidikan Matematika, 10(1): 50-60.

Febriyanti \& Seruni. (2014). Peran minat dan interaksi siswa dengan guru dalam meningkatkan hasil belajar matematika. Jurnal Formatif, 4 (3): 245-254. 
Fitriyani, R. (2019). Hubungan minat belajar dan intensitas belajar dengan prestasi belajar matematika siswa kelas vii smp negeri 1 karanganom. ABSIS: Mathematics Education Journal, 1(1).

Handayani, S. (2016). Pengaruh perhatian orangtua dan minat belajar matematika terhadap prestasi belajar matematika siswa. Formatif: Jurnal Ilmiah Pendidikan MIPA, 6(2): 141-148.

Haryati, N. (2015). Hubungan minat belajar dengan prestasi belajar matematika siswa kelas v sd se-gugus wonokerto turi sleman tahun ajaran 2014/2015. Basic Education, 4(13): 1-11.

Heriyati, H. (2017). Pengaruh minat dan motivasi belajar terhadap prestasi belajar matematika. Formatif: Jurnal Ilmiah Pendidikan MIPA, 7(1): 22-32.

Islamiah, I. D. (2019). Pengaruh minat belajar siswa terhadap prestasi belajar matematika di SMKN 1 Cihampelas. Journal on Education, 1(2): 451-457.

Kompri. (2017). Belajar, faktor-faktor yang mempengaruhinya. Yogyakarta: Media Akademi.

Lase, S. (2018). Hubungan antara motivasi dan kebiasaan belajar terhadap prestasi belajar matematika siswa smp. Jurnal Warta Edisi, 56: 1-829.

Lestari, I. (2013). Pengaruh waktu belajar dan minat belajar terhadap hasil belajar matematika. Jurnal Formatif, 3 (2): 115-125.

Mutakin, TZ dan Teti, S. (2011). Pengaruh penggunaan media belajar terhadap hasil belajar matematika. Jurnal Formatif, 1 (1): 70-81.

Putri, F. D. (2017). Hubungan minat belajar terhadap prestasi belajar matematika siswa kelas IV SD Negeri se-Gugus Mawar Metro Pusat. Skripsi. PGSD, Universitas Lampung.

Rahma, H. A., \& Ardani, A. (2018). Pengaruh interaksi edukatif terhadap hasil belajar matematika siswa. Jurnal Dialektika Program Studi Pendidikan Matematika, 5(1): 81-89.

Ratnasari, I. W. (2017). Hubungan minat belajar terhadap prestasi belajar matematika. Psikoborneo, 5(2): 400-405.

Sardiman. (2011). Interaksi dan motivasi belajar-mengajar. Jakarta: PT Rajagrafindo Persada.

Sari, F. K., Rakimahwati, R., \& Fitria, Y. (2019). Hubungan minat dengan hasil belajar peserta didik pada pembelajaran matematika kelas VI SDN 25 Jati Tanah Tinggi. Jurnal Basicedu, 3(2): 397-405.

Siagian, R. E. F. (2015). Pengaruh minat dan kebiasaan belajar siswa terhadap prestasi belajar matematika. Formatif: Jurnal Ilmiah Pendidikan MIPA, 2(2): 122-131.

Sirait, E. D. (2016). Pengaruh minat belajar terhadap prestasi belajar matematika. Formatif: Jurnal Ilmiah Pendidikan MIPA, 6(1): 35-43.

Slameto. (2010). Belajar dan faktor-faktor yang mempengaruhinya. Jakarta: Rineka Cipta.

Sugilar, H. (2013). Meningkatkan kemampuan berpikir kreatif dan disposisi matematik siswa madrasah tsanawiyah melalui pembelajaran generatif. Jurnal Ilmiah Program Studi Matematika STKIP Siliwangi Bandung, 2 (2): 156-168.

Susintoi. (2019). Hubungan antara disiplin, mandiri, interaksi edukatif dan minat belajar dengan hasil belajar matematika di sekolah dasar. Tesis. FKIP, Universitas Tanjungpura.

Turmudi. (2012). Matematika landasan filosofis, didaktis, dan pedagogis pembelajaran matematika untuk siswa sekolah dasar. Jakarta: Kementrian Agama Republik Indonesia.

Widiyawati, R. (2013). Hubungan minat belajar dengan hasil belajar matematika siswa kelas VIII SMP Negeri 10 Malang semester genap tahun ajaran 2012/2013. Skripsi. Jurusan Matematika-Fakultas MIPA UM. 